Гродзь Наталія Миколаївна аспірантка кафедри педагогіки та інноваційної освіти, Національний університет "Львівська політехніка", вул. Степана Бандери, 12, Львів, 79000, тел.: (096) 444-10-55, e-mail: omarow998@ukr.net, https://orcid.org/0000-0003-1577-1214

\title{
ХАРАКТЕРИСТИКА ПРОТИДІЇ НЕГАТИВНОМУ ВПЛИВУ СОVID-19 В ЗАКЛАДАХ ВИЩОЇ ОСВІТИ ПРОВІДНИХ КРАЇН СВІТУ
}

Анотація. Причиною пандемічного поширення коронавірусу більшість вчених вбачають той факт, що дана хвороба маніфестує у кожної окремої людини по-різному: від безсимптомного перебігу до тяжкої легеневої недостатності 3 обов'язковою кисневою підтримкою. На різних етапах кризи в галузі охорони здоров'я уряди ухвалювали політику щодо блокування соціальної діяльності, щоб стримати поширення пандемії, ненавмисно створивши світову економічну рецесію. 3 огляду на вражаючі негативні наслідки пандемії COVID-19, більшість країн світу усвідомили важливість облігативного та невідкладного впливу на всі сфери суспільства, як на рівні окремої країни, так і міжнародному рівні. Більшість урядів доклали значних зусиль для того, щоб розробити дієві стратегії відновлення враженою пандемією економіки та інших суспільних сфер. В основі цих стратегій були поступові впровадження пакетів стимулів та фінансова допомога, що направлена на допомогу тим сферам життєдіяльності країни та світу, які опинились в кризовій ситуації. Окрім того, деякі країни запровадили окрему фінансову допомогу найуразливішим верствам населення, які в силу діяльності пандемічних обмежень опинились за межею бідності. Торкнулося це i системи вищої освіти, яка суттєво змінили свої правила функціонування у закладах.

Метою дослідження $є$ характеристика протидії негативному впливу COVID-19 в закладах вищої освіти провідних країн світу. Для цього було проведено дослідження зарубіжного досвіду та застосовано ряд теоретиконаукових методів аналізу та синтезу опрацьованої інформації. Встановлено, що COVID-19 став справжнім випробуванням для вищих навчальних закладів по всьому світу з точки зору їх рівня готовності, гнучкості та адаптивності в реагуванні на аналогічні глобальні кризи. Визначено, що у світі більшість шкіл, коледжів і університетів закриті, щоб контролювати поширення COVID-19. Закриття школи створює труднощі для учнів, сімей і вчителів.

Ключові слова: пандемія, COVID-19, освіта, заклади освіти, вплив.

Grodz Natalia Mykolaivna Postgraduate student of the Department of Pedagogy and Innovative Education, Institute of Law, Psychology and Innovative Education of Lviv Polytechnic National University, Stepana Bandera St., 12, Lviv, 79000, tel .: (096) 444-10-55, e-mail: omarow998@ukr.net, https://orcid.org/0000-0003-1577-1214 


\section{CHARACTERISTICS OF COUNTERACTING THE NEGATIVE IMPACT OF COVID-19 IN HIGHER EDUCATION INSTITUTIONS OF THE WORLD'S LEADING COUNTRIES}

Abstract. Most scientists see the reason for the pandemic spread of coronavirus to the fact that this disease manifests itself in each individual person in different ways: from asymptomatic to severe pulmonary insufficiency with mandatory oxygen support. At various stages of the health crisis, governments have adopted policies to block social activity to contain the spread of the pandemic, inadvertently creating a global economic recession. Given the impressive negative consequences of the COVID-19 pandemic, most countries in the world have realized the importance of urgently influencing all spheres of society, both at the national and international level. Most governments have made significant efforts to develop effective strategies for rebuilding the pandemicstricken economies and other public spheres. These strategies were based on the gradual introduction of stimulus packages and financial assistance aimed at helping the spheres of life of the country and the world in crisis situations. In addition, some countries have introduced separate financial assistance to the most vulnerable segments of the population, who, due to the activities of pandemic restrictions, have found themselves below the poverty line. This also affected the higher education system, which significantly changed its rules for functioning in institutions.

The aim of the study is to characterize the counteraction to the negative impact of COVID-19 in institutions of higher education in the leading countries of the world. For this, a study of foreign experience was carried out and a number of theoretical and scientific methods of analysis and synthesis of the developed information were applied. It has been established that COVID-19 has become a real challenge for higher education institutions around the world in terms of their level of preparedness, flexibility and adaptability in responding to similar global crises. It has been determined that most schools, colleges and universities in the world are closed to control the spread of COVID-19. School closures create difficulties for students, families and teachers.

Keywords: pandemic, COVID-19, education, educational institutions, impact.

Постановка проблеми. Повідомляється, що понад 1 мільярд 575 мільйонів студентів приблизно в 188 країнах світу постраждали від закриття шкіл і університетів через превентивних заходів, прийнятих країнами проти поширення COVID-19. Через ізоляції використання технологій вважається найбільш придатною (якщо не єдиною) альтернативою для підтримки працездатності освітніх систем в багатьох частинах світу в цей період. Незважаючи на проблеми в реалізації, було визнано кілька переваг у необхідності переходу до дистанційного або онлайн-навчання, серед яких виділяється можливість швидкого прогресу в області цифрового освіти, на який в інших обставинах будуть потрібні роки. Перехід до формату дистанційного навчання являється хорошою можливістю для вчителів і учнів стати більш творчими. Поширення 
COVID-19 також викликало страх, занепокоєння і інші побоювання у громадян в різних частинах світу, включаючи групи, які беруть участь в освітньому процесі, такі як діти, вчителі та батьки. Передбачається, що на занепокоєння батьків, крім обставин, створених через фізичного дистанціювання та інших особистих факторів, вплинули: небажання підтримувати своїх дітей в дистанційному / онлайн-навчанні або домашньому навчанні; відсутність доступу до технологій і Інтернету або неадекватність технологічних форматів, використовуваних для дітей з особливими освітніми потребами; економічні труднощі. Було відзначено, що стурбованість вчителів, залучених до процесу навчання, пов'язана 3 можливостями проведення дистанційного / онлайн-навчання через їх рівня знань i навичок у використанні технологій, доступу до технологій і ізоляції будинку. Про таких побоюваннях повідомляли, зокрема, країни, в яких до виникнення обставин, створених превентивними заходами проти поширення COVID-19, рівень використання технологій учителями в класі був оголошений надзвичайно низьким. Крім того, вимоги перевести викладання в онлайн-формат підвищили рівень стресу і занепокоєння вчителів в різних частинах світу. Хоча перехід до онлайн-навчання вже став частиною багатьох систем освіти в світі, вважається, що рівень використання і способи використання технологій для досягнення якості дистанційного або онлайн-навчання розрізняються. Цей рівень залежить від багатьох факторів, пов'язаних з різними сторонами, які беруть участь в реалізації цього формату навчання та інтеграції технологій в системи освіти до періоду закриття шкіл в результаті пандемії COVID-19. Протягом багатьох років численні дослідження по всьому світу були зосереджені на виявленні факторів, які роблять інтеграцію технологій успішної в викладанні і навчанні в класі. Передбачається, що одні й ті ж фактори впливають на рівень використання технологій в процесах перекладу навчання зі школи в дистанційний або онлайнформат, а також на якість навчання в обох форматах. Саме тому, дуже актуальним є обрана тематика дослідження.

Аналіз останніх досліджень і публікацій. Важливі аспекти підготовки студентів в закладах вищої освіти висвітлюються такими ученими як М. Блаут, Т. Боголіб, В. Бородюк, Х. Боуен, А. Віфлеємський, О. Грішнова, та інші. Однак настання пандемії i вплив COVID-19 суттєво змінити правила ведення педагогічної діяльності, що і зумовило вибір даної тематики і іï сучасну актуальність.

Метою статті є характеристика протидії негативному впливу COVID-19 в закладах вищої освіти провідних країн світу.

Виклад основного матеріалу. Важливим буде визначення кроків окремих держав у подоланні пандемічної кризи в сфері освіти. Як ми вже згадували, на сьогоднішній день всі заходи урядів країн щодо підтримки сфери освіти, можна поділити на дев'ять основних категорій. Відповідно цього, доцільним буде розглянути досвід протидії коронавірусній кризі в сфері освіти відповідно найбільш популярних категоріям.

Якщо розглядати першу категорію заходів «Інформаційна підтримка системи 
освіти на регіональному та загальнодержавному рівні», то дана група відповідає за надання актуальної та достовірної інформації про становище сфери освіти, а також наступних заходів держави щодо ії підтримки.

Яскравими прикладам країн, які застосували найбільше заходів даної категорії, є такі держави як Франція, Нова Зеландія та Фінляндія. За активної підтримки урядів цих держав, на сайті відомств та міністерств сфери освіти були створені спеціальні розділи та посилання, в яких йшла мова про основні заходи уряду щодо протидії негативним наслідкам пандемії COVID-19, а також мінімізації вже існуючим проблемам.

До прикладу, на сайті Генерального директорату освіти Франції опубліковані всі підзаконні акти, законодавчі документи, а також рекомендації, інструкції та антикризові плани щодо подолання наслідків пандемії. Окрім того, в цих ресурсах можна знайти зворотній зв'язок з урядовими структурами, за допомогою якого можна знайти інформацію на всі питання щодо продовження освітнього процесу в часи пандемічних обмежень [15, с.11].

Управління по справам студентів Великобританії у відкритому доступі надав всім бажаючим інформацію про досвід та приклади найбільш успішних освітніх закладів, які змогли організувати свою роботу в часи пандемічних обмежень. Окрім того вони організували безкоштовні лінії психологічної підтримки для тих осіб, які опинились в кризовій ситуації внаслідок пандемії. Зокрема це стосується студентів-сиріт, а також іноземних студентів, які не змогли покинути країну до початку локдауну [17, с.18].

Друга група заходів «Надання рекомендації для різних сфер системи освіти щодо дотримання санітарно-епідеміологічних заходів превенціїі коронавірусної хвороби» найбільш часто використовувалась по світу.

В структурі цієї категорії, країни впроваджували заходи санітарноепідемічного характеру (табл.1).

Таблиия 1

\section{Основні санітарно-епідеміологічні заходи, які направлені на профілактику поширення COVID-19 в закладах освіти}

\begin{tabular}{|c|c|}
\hline № & Основні санітарно-епідеміологічні заходи \\
\hline 1 & $\begin{array}{c}\text { Суворе дотримання всіх стандартів та норм гігієни в часи пандемії(часте миття рук та } \\
\text { наступна обробка їх антисептичними розчинами) }\end{array}$ \\
\hline 2 & Суворий масочний режим \\
\hline 3 & Дотримання соціальної дистанції \\
\hline 4 & $\begin{array}{c}\text { Регулярна санітарна обробка приміщень антисептичними розчинами а також їх часте } \\
\text { провітрювання }\end{array}$ \\
\hline 5 & $\begin{array}{l}\text { Постійний моніторинг стану здоров'я студентського та викладацького складу (температурний } \\
\text { скринінг, періодичне ПЛР-тестування, а також контроль та виявлення ранніх симптомів, } \\
\text { властивих коронавірусній хворобі з наступною ізоляцією хворих та контактних осіб) }\end{array}$ \\
\hline
\end{tabular}

Цікавою є практика Італії в реалізації протиепідемічних заходів. Так як в 
період карантину існує заборона щодо масових зібрань, то проблематичним виявилось просте відвідування лекційних аудиторій. 3 огляду на це, на загальнодержавному рівні було рекомендовано використовувати такі додатки як «EasyRoom» или «AppPosto», за допомогою яких студенти можуть забронювати собі місце на конкретній лекції [21]. 3 огляду на складну епідемічну ситуацію в Італії в 2020 році, уряд ухвалив доволі жорсткі норми щодо моніторингу та виявленню хворих. Так, у разі виявлення хворого на коронавірусну хворобу, який встиг відвідати учбових заклад, то інформація про даний випадок передавалась в органи місцевого самоврядування, в яких вже ухвалювалось рішення про часткове чи повне припинення функціонування корпусу, гуртожитку чи іншої структурної одиниці учбового закладу.

Наступною доволі популярною категорією заходів допомоги та підтримки системи освіти на загальнодержавному рівні $\epsilon$ реалізація адміністративних заходів щодо підтримання та збереження функціонування закладів освіти різних розмірів та рівнів акредитації.

Більшість країн світу намагались створити тимчасові адміністративні норми щодо підтримання функціонування та регуляції епідемічного функціонування закладів освіти з акцентом на збереження стандартів якості освіти.

До прикладу, в США було видано «Положення про дистанційне навчання та інноваційну діяльність закладів освіти в часи пандемії», в якому було роз'яснено всі проблемні зони впровадження дистанційного навчання [19].

У Франції був прийнятий «План безперервної освіти», в якому містилась інформація для студентів та викладачів щодо питань формування програми дистанційної освіти, контролю очної взаємодії викладачів та студентів, формування та адаптація існуючих учбових планів та пандемічних реалій, організації вступної та екзаменаційної компанії та інших питань. Окрім того, в цьому документі містились також нормативно-законодавчі акти щодо регуляції діяльності університету в часи пандемії, забезпечення безперервності стипендіальних програм та додаткової допомоги іноземним студентам

Відповідно цього Плану, всі учбові плани закладів освіти повинні мати свої електронні копії з можливістю їх подальшої корекції. Відмінною особливістю досвіду цієї країни можна вважати те, що на державному рівні було ухвалено дозвіл на проведення дистанційних зустрічей та засідань колегіальних органів закладів освіти, профсоюзів та інших організацій [22].

У Великобританії були прийняті нормативно-законодавчі акти, які регламентували послаблення вимог до строків та способів подачі документів до закладів освіти, а також впровадження лояльної системи проходження вступних та випускних екзаменів. Окрім того, в цій країні на державному рівні були утворені обов'язкові онлайн-курси щодо підвищення рівня знань викладачів у сфері організації та проведення дистанційних форм навчання [23].

Очевидно, що COVID-19 став справжнім випробуванням для вищих навчальних закладів по всьому світу з точки зору їх рівня готовності, гнучкості та адаптивності в реагуванні на аналогічні глобальні кризи. Проте, з іншого боку, 
він $\epsilon$ ефективним «агентом змін», що сприяє швидкому впровадженню електронного навчання в таких класично чинять опір змінам навчальних закладах.

Важливо проаналізувати уроки, витягнуті 3 поточного досвіду, щоб вищі навчальні заклади були краще підготовлені до можливого розширення екстреного електронного навчання в майбутньому осінньому семестрі. Приклади цих засвоєних уроків включають, але не обмежуються:

1. Рівний доступ учнів до дистанційного методу навчання не слід сприймати як щось само собою зрозуміле. Дуже важливо заздалегідь ретельно оцінити потреби студентів і їх технічні характеристики.

2. Ще рано думати, що дистанційне навчання - єдина життєздатна альтернатива заміна очного навчання. Живе спілкування між учнями та вчителями як і раніше необхідно підтримувати в онлайн-середовищі.

3. Оцінка успішності студентів в онлайн-середовищі залишається складним завданням як для викладачів, так і для студентів, особливо при оцінці практичних навичок, технічних навичок i навчальної практики. Тому важливо використовувати різні типи альтернативних методів оцінки і відповідні онлайнрубрики.

4. Хоча навички цифрової грамотності виявилися найважливішою умовою для викладачів при проведенні онлайн-занять, потреба в навчанні викладачів в області навчального дизайну стає все більш важливою потребою в навчанні. Щоб знизити навантаження на викладачів, це може бути надано у вигляді вбудованих електронних систем підтримки у вигляді готових шаблонів.

5. Як і очікувалося, цей екстрений досвід електронного навчання показав, що цифрові навички студентів, схоже, набагато перевершують навички більшості їхніх викладачів. Однак готовність учнів до електронного навчання вимагає високого рівня мотивації і навичок саморегуляції.

Висновки. Підсумовуючи, зазначимо, що COVID-19 - це пандемічне захворювання, викликане вірусом, що вражає систему освіти як в країнах, що розвиваються, так і в розвинених країнах. Освіта - це основа розвитку кожної країни. У світі більшість шкіл, коледжів і університетів закриті, щоб контролювати поширення COVID-19. Саме тому, вкрай важливим сьогодні $\epsilon$ продовжувати проводити дослідження даної проблематики.

\section{Jimepamypa:}

1. Influenza pandemic planning guide for early childhood education services, schools and tertiary organisations // Ministry of Education. 08.2020. URL: https://www.education.govt.nz/assets/ Documents/Ministry/Initiatives/Health-and-safety/PandemicPlanningGuideForEdSectorAug2011.doc

2. COVID-19 bulletins for tertiary education providers and students // Ministry of Education.URL: https://www.education.govt.nz/further-education/covid-19-bulletins-for-tertiaryproviders-and-students/

3. Masks and online booking: How Italy's universities plan to reopen after lockdown // The Local. 25.08.2020. URL: https://www.thelocal.it/20200825/half-empty-lectures-and-booking-requires- howitalys-universities-plan-to-reopenafter-lockdown 
4. COVID-19 and higher education: Today and tomorrow. Impact analysis, policy responses and recommendations // UNESCO IESALC. 13.05.2020. URL: https://www.iesalc.unesco.org/en/wpcontent/uploads/2020/05/COVID-19-EN-130520.pdf

5. OECD, Education Responses To Covid-19: Embracing Digital Learning And Online Collaboration, https://oecd.dam-broadcast.com/pm_7379_120_120544-8ksud7oaj2.pdf

\section{References:}

1. Influenza pandemic planning guide for early childhood education services, schools and tertiary organisations (2020) Ministry of Education. 08.2020. URL: https://www.education.govt.nz/ assets/Documents/Ministry/Initiatives/Health-and-safety/PandemicPlanningGuideForEd SectorAug2011.doc [in English]

2. COVID-19 bulletins for tertiary education providers and students (2020) Ministry of Education.URL: https://www.education.govt.nz/further-education/covid-19-bulletins-for-tertiary-providersand-students/ [in English]

3. Masks and online booking (2020): How Italy's universities plan to reopen after lockdown // The Local. 25.08.2020. URL: https://www.thelocal.it/20200825/half-empty-lectures-and-bookingrequires-how-italys-universities-plan-to-reopenafter-lockdown [in English]

4. COVID-19 and higher education (2020): Today and tomorrow. Impact analysis, policy responses and recommendations // UNESCO IESALC. 13.05.2020. URL: https://www.iesalc.unesco.org/en/wpcontent/uploads/2020/05/COVID-19-EN-130520.pdf [in English]

5. OECD, Education Responses To Covid-19 (2020): Embracing Digital Learning And Online Collaboration, https://oecd.dam-broadcast.com/pm_7379_120_120544-8ksud7oaj2.pdf [in English] 